\title{
Sports effect on depression level of elementary school students
}

\author{
Ahmet Gursel OGUZ, Oksay OGUZ \\ Faculty of Sport Sciences, Selçuk University, Konya, Turkey. \\ Address correspondence to A. G. Oguz, e-mail: agoguz@selcuk.edu.tr
}

\begin{abstract}
The purpose of this study is to analyze sports and exercises effects on depression levels of elementary school students. The research group formed a total of 203 students, including 104 students who exercise (amateur athletes, playing in school teams, etc.) The Depression Scale for Children (CDS) and Beck Depression Scale was used as a data collection tool in the study. The applicability of parametric or nonparametric tests was examined by comparing the normal distribution of values and variance equality when analyzing data to measure depression level of subjects. The normal distribution fitness test for the data was tested using the Kolmogorov-Smirnov test, again using the Levene' test for variance homogeneity. In order to apply the parametric tests, both normal distribution suitability and variance homogeneity are required. Non-normal distribution of data or homogeneous variance requires using nonparametric tests. One-way ANOVA test for more than two group of parametric tests and two independent T-tests for two independent groups were used for the analysis of the data as a result of Kolmogorov-Smirnov test and Levene' test. The difference between the two independent sample T-test results for determining whether the depression scores of the performing and non-performing individuals are different is $\mathrm{P}=0.039$ $<0,05$.According to this, doing sports affects the score of depression. Individuals doing sports were found to be lower than students who did not score depression. There was no significant difference in the number of other siblings, age, educational status, maternal profession, father's occupation, mother education, father education, income and sex variables, depression scores were compared at 0.05 level. As a result, it was found that sports and exercise were important in reducing the adverse effects of depression or entering primary school children. In addition, emphasis should be placed on the preparation of adolescents for the direction of children's spores.
\end{abstract}

Keywords: Child, depression, exercise, sports.

\section{INTRODUCTION}

Game and sport activities play an important role in the development process of children's life. Children are eager to learn the movements and they are delighted to try them. As long as they maintain their physical control, they feel confident that they are successful. They do not need external reasons to play and develop their skills. Because the children have the motivation for this. Therefore, when sports applications are being organized for children, appropriate environments in which they can learn physical skills must be created, and certainly should not be difficult for top-class sporting performance. The goal is not to create a feeling of failure, but to live a sense of success. Otherwise their social development may be delayed (13). Depression in primary school children is a mental disorder that affects the individual's performance in different areas, such as in adulthood, and can lead to significant problems if not treated. The positive effects of sports and physical activity on physical health as well as mental health benefits are known. When the resources are examined, it is seen that the work done in this area belongs more to the period of adulthood. In studies conducted with adolescents in recent years, it has been determined that physical activities have a positive effect on self-perception, peer-to-peer relationships, and academic achievement $(6,16)$.

In primary school children, depression can affect an individual's performance in different areas and can lead to major problems if not resolved. In addition, depression is a psychological deformity that can experience adversities during adolescence.

Compared to the number of studies examining the relationship between physical activity and physical health, it will be seen that the work on the psychosocial health effect is very limited. Studies on 
the effects of sports activities on mental health generally focus on four dimensions. These; Emotionstate, fear, depression and self-image (8).

Depression is a syndrome that contains symptoms such as deep sadness or thinking in a situation, slowing and stagnation in speech and movements, worthlessness, smallness, weakness, reluctance, pessimism, feelings and thoughts, and slowdown in physiological functions (13). Depression includes versatile symptoms such as cognitive difficulty, a pessimistic view of the world, graceful emotional state, inwardness in social relationships, decrease in physical energy level, restlessness, low self-worth, increased self-related feelings of guilt, instrumental despair and learned helplessness (3).

In primary school children, depressive situations occur for some reason and force the child to exhibit negative behaviors. These depressive situations need to be resolved so that the child can live in a healthy way. Sports and exercise are also one of these solutions. It is known that the sport which is an important part of social life not only raises the quality of life but also has a therapeutic effect on depression (5).

It is known that besides physical and physiological benefits of exerting participation, it reduces tension, provides psychological well-being and is among the treatment methods of psychiatric rehabilitation programs (12).

During sports events children and young people are directed to work together. While contributing to the development of friendship sentiments, it gives them the ability to work together, social responsibilities and leadership. It also prevents aggressive behaviors while enhancing the ability of one person to cooperate with others and become a good spectator, providing self-esteem, love and selfreliance to oneself and others (14).

In a study conducted by Akandere (1), university students who did or did not have a significant difference in depression levels showed lower levels of depression than those who did not. The sport, which has a history dating back to the beginning of human history, draws attention as an important part of social life. Sports has started to take an important place in everyday life by gaining new meanings, such as economic conditions, industrialization, intense urbanization, free time increase, individual health concerns and so on. In addition to being used for sport performance purposes, it also stands out with its aim of promoting healthy life or other various quality of life (11).

It has been observed that elementary school children are more hard-working, more vigorous, more prepared to engage in relationships, and better adapted to difficult conditions than those who do sports. Sportsmen are more outward-oriented and emotionally balanced than non-sportsmen (15).

Research has shown that sport or physical activity has an effect on depression and mental health and is used as a treatment method in depressive situations. There are significant differences in the frequency of depression among those who do sports and those who do not. This study may be necessary and important in terms of shedding light on children, parents, and teachers in order to determine depressive situations and sports effects seen in primary school children.

\section{MATERIALS \& METHODS}

\section{Model of Research}

It has been descriptively and descriptively studied for the purpose of studying the depression situations according to some variables from the students who read primary education, do sport and do not play sports.

\section{Universe-Sample}

Two hundred-three primary school age students (101 boys and 102 girls), including 99 non-sports who did 104 sports, constituted the universe of the research.

\section{Data Collection Technique}

The "Children's Depression Scale (CDS)" developed by Kovaks (1979) Beck Depression Scale (1961) was used as a data collection tool and a 9question questionnaire that determined sociodemographic characteristics in the study.

\section{Data Collection Analysis}

The normal distribution of the fitness test for the data was tested using the Kolmogorov-Smirnov test, again using the Levene' test for variance homogeneity. In order to apply parametric tests, both normal distribution fitness and variance homogeneity are required at the same time. The fact that the data are not homogeneous variants and that they are not normally distributed requires using nonparametric tests. ANOVA (One-way ANOVA) test were used for more than two groups from parametric tests and two independent t-tests for 
independent two groups. SPSS 15 Statistical Package Program was used in the analysis of the data. The significance level was determined as $\alpha=0.05$.

\section{RESULTS}

The results of the statistical analyzes obtained by questionnaire presented in tabular below. The scores from Children's Depression Scale were the main data of these analyzes.

There was no significant relationship between depression statuses according to the sex of children in primary education age ( $p>0.05$; Table 1$)$.
There was no significant association between primary school children's age and depression ( $p>$ 0.05; Table 2).

According to the number of siblings of elementary school children, the value found in distribution of depression status ( $p>0.05$; Table 3) was high and no significant relation was found.

There was no significant relationship between the prevalence of depression $(p>0.05)$ in the distribution of depression according to the education of primary school children (Table 4).

Table 1. Distribution of depression according to gender of primary school children.

\begin{tabular}{lccccc}
\hline Gender & $\mathrm{N}(\%)$ & Mean & $\mathrm{SD}$ & $\mathrm{t}$ & $\mathrm{p}$ \\
\hline Male & $101(49.8)$ & 12.70 & 0.32 & 0.216 & 0.829 \\
Female & $102(50.2)$ & 12.60 & 0.36 & & \\
\hline
\end{tabular}

Table 2. Distribution of depression according to the age of primary school students.

\begin{tabular}{lcccccc}
\hline Age & $\mathrm{n}$ & $\%$ & Mean & SD & F & $\mathrm{p}$ \\
\hline $9-10$ & 43 & 21.2 & 12.139 & 0.481 & .819 & .442 \\
$11-12$ & 117 & 57.6 & 12.897 & 0.324 & & \\
13 and above & 43 & 21.2 & 12.488 & 0.543 & & \\
\hline
\end{tabular}

Table 3. Distribution of the number of siblings with respect to siblings of primary education students.

\begin{tabular}{lcccccc}
\hline Siblings & $\mathrm{n}$ & $\%$ & Mean & SD & F & $\mathrm{p}$ \\
\hline $1-2$ & 124 & 61.0 & 12.73 & 0.32 & 0.101 & 0.904 \\
$3-4$ & 73 & 36.0 & 12.51 & 0.38 & & \\
5 and above & 6 & 3.0 & 12.83 & 1.25 & & \\
\hline
\end{tabular}

Table 4. Distribution of depression according to education level of primary school students.

\begin{tabular}{lcccccc}
\hline Education Status & $\mathrm{n}$ & $\%$ & Mean & SD & F & $\mathrm{p}$ \\
\hline Primary School & 194 & 95.6 & 12.66 & 0.248 & .079 & .779 \\
High School & 9 & 4.4 & 12.33 & 1.105 & & \\
\hline
\end{tabular}

Table 5. Distribution of depression according to maternal occupational status of primary school children.

\begin{tabular}{lcccccc}
\hline Mother's Job & $\mathrm{n}$ & $\%$ & Mean & SD & F & $\mathrm{p}$ \\
\hline Housewife & 139 & 68.5 & 12.91 & 0.296 & 1.654 & .194 \\
Public & 51 & 25.1 & 12.29 & 0.472 & & \\
Private & 13 & 6.4 & 11.31 & 0.811 & & \\
\hline
\end{tabular}


Table 6. Depression distribution according to father's occupational status of primary school children.

\begin{tabular}{lcccccc}
\hline Father's Job & $\mathrm{n}$ & $\%$ & Mean & SD & F & $\mathrm{p}$ \\
\hline Self-employment & 71 & 35.0 & 12.90 & 0.41 & .417 & .660 \\
Public & 90 & 44.3 & 12.41 & 0.36 & & \\
Private & 42 & 20.7 & 12.74 & 0.55 & & \\
\hline
\end{tabular}

Table 6. Depression distribution according to father's occupational status of primary school children.

\begin{tabular}{lcccccc}
\hline Father's Job & $\mathrm{n}$ & $\%$ & Mean & SD & F & $\mathrm{p}$ \\
\hline Self-employment & 71 & 35.0 & 12.90 & 0.41 & .417 & .660 \\
Public & 90 & 44.3 & 12.41 & 0.36 & & \\
Private & 42 & 20.7 & 12.74 & 0.55 & & \\
\hline
\end{tabular}

Table 7. Distribution of depression according to mother's educational status in primary school children.

\begin{tabular}{lcccccc}
\hline Mother's Education & $\mathrm{n}$ & $\%$ & Mean & SD & F & $\mathrm{p}$ \\
\hline Primary School & 75 & 36.9 & 12.36 & 0.39 & .496 & .610 \\
High School & 59 & 29.1 & 12.95 & 0.37 & & \\
University & 69 & 34.0 & 12.71 & 0.48 & & \\
\hline
\end{tabular}

Table 8. Depression distribution of primary school children according to their father's education status.

\begin{tabular}{lcccccc}
\hline Father's Education & $\mathrm{n}$ & $\%$ & Mean & SD & F & $\mathrm{p}$ \\
\hline Primary School & 45 & 22.21 & 12.60 & 0.54 & .966 & .382 \\
High School & 60 & 29.6 & 13.15 & 0.46 & & \\
University & 98 & 48.3 & 12.37 & 0.33 & & \\
\hline
\end{tabular}

Table 9. Distribution of depression according to family income level of primary school children.

\begin{tabular}{lcccccc}
\hline Income & $\mathrm{n}$ & $\%$ & Mean & SD & F & $\mathrm{p}$ \\
\hline Low & 7 & 3.4 & 13.14 & 1.55 & .079 & .924 \\
Middle & 152 & 74.9 & 12.68 & 0.28 & & \\
High & 44 & 21.7 & 12.68 & 0.51 & & \\
\hline
\end{tabular}

Table 10. Distribution of depression according to non-sporting behaviors of primary school children.

\begin{tabular}{lcccccc}
\hline & $\mathrm{n}$ & $\%$ & Mean & SD & F & $\mathrm{p}$ \\
\hline Do sports & 104 & 51.2 & 12.16 & 0.31 & -2.080 & $0.039^{*}$ \\
Not do sports & 99 & 48.8 & 13.16 & 0.37 & & \\
\hline${ }^{*} \mathrm{P}<0.05$ & & & & & &
\end{tabular}


There was no significant association between primary school children and their mothers' profession ( $p>0.05$; Table 5).

There was no significant association between primary school children and their father's occupation, as the value found in the distribution of depression status was high ( $p>0.05$; Table 6$)$.

There was no significant relationship between the primary school children and the mothers' education ( $p>0.05$; Table 7 ).

There was no significant relationship between primary school children's depression status distribution ( $p>0.05$; Table 8) and high school secondary school children's education level.

There was no significant relationship between primary school children's level of depression according to family income level ( $p>0.05$; Table 9).

The difference between the two independent sample t-tests for the test of whether the depression scores of the non-performing and non-performing individuals were different was $p=0.039$. According to this, doing sports affects the score of depression. Individuals doing sports were found to be lower than those who did not score depression.

\section{DISCUSSION}

According to the findings obtained in this study, when analyzed according to whether or not depression levels of the subjects participating in sports research p-value $(0.039<0.05)$ was found a statistically significant difference found that low. Arslan et al. (2) found a significant difference between depression scores of primary school students who did sports and primary school students who did not play sports. According to the findings of the study, there was no significant difference between depression scores of female and non-athletic students but it was found that female students who did not exercise had higher depression scores. In another study, it was determined that the athletes were more outwardly and emotionally balanced (15). Sports that students, for students who do sport physically, spiritually and mentally that feels comfortable, stress-free, can produce comfortable solutions across problems, living less stress, can be characterized as individuals who own selfconfidence. According to the gender of the subjects of depression (Table 1) as a result of comparing the value of pi points to a significant relationship was observed due to the high rise. Arslan et al. (2) found a statistically significant difference between depression scores of boys who did sports and boys who did sports. In addition, there was no statistically significant difference between depression scores of female students who did sports and female students who did not. Differences in gender are observed in most of the studies done in adolescents.

Differences in gender are observed in most of the studies done in adolescents $(7,9,10)$. Both studies also found that both depressive symptoms and depression were more common in women than in men $(4,7)$.

There was no significant association between primary school children depression levels according to their ages (Table 2) and high p value due to their scores. In the researches of Arslan et al. (2), there was no significant difference between depression scores according to the ages of the students who did sports and did not do sports. This result is in agreement with our study results. There was no significant association between the levels of depression according to income level (Table 9) as a result of the high $\mathrm{p}$ value. Arslan et al. (2) determined that the students who did not play sports had higher levels of depression as the income level of their families increased. As the economic level rises, the child may be more interested in activities he or she is interested in. As the socio-economic level of the family is low, the child cannot fulfill his or her wishes, which has the negative effect that the child does not feel safe (17).

As a result, the difference between two independent sample T-tests for the test of whether the depression scores of the non-athletes and nonathletes were different was found to be $p=0.039$. According to this, doing sports affects the score of depression. Individuals doing sports were found to be lower than those who did not score depression. There was no significant difference between the depression scores of the other Number of Siblings, Age, Education Status, Maternity Profession, Father Profession, Mother Education, Father Education, Income and sex variables compared to $\mathrm{p}>0.05$.

There are many different factors that cause depression, as well as many techniques for treatment and prevention. Commonly used treatment techniques include drugs, psychotherapy, and electroconvulsive therapy (ETC). In addition to these studies, the results of recent researches reveal positive effects of sports and regular simple exercises on depression prevention and treatment. Research on 
sports and psycho-social aspects of sports in the world and in Turkey has begun to be done on a large scale. Many researchers examined the effect of sports on mental health and findings were found to be related to the role of sports in depression and in the treatment of depression. Research has revealed that sport has strengthened both body and soul health. From the physiological point of view, it has been determined that hormones that produce antidepressant effects, especially hormones such as dopamine, serotonin, and endorphin, increase the secretion of the hormone which provides pleasure and pleasure to the human being. It has also been proven that those who regularly play sports better with stress, and rarely face anxiety and depression.

\section{REFERENCES}

1. Akandere M. Spor yapan ve yapmayan öğrencilerin depresyon düzeylerinin incelenmesi. Sports and Medical Journal, Syndrome, 2003; 4,2,1.

2. Aslan C, Güllü M, Tutal V. Spor yapan ve yapmayan ilköğretim öğrencilerinin depresyon durumlarının bazı değişkenlere göre incelenmesi. Niğde University J Physical Education and Sports Science, 2011; 5(2).

3. Brendt DJ, Brendt SM. Relationship of mild depression to psychological deficit in college students. Journal of Clinical Psychology, 1980; 96(1): 868-874.

4. Cohen PJ, Kasen S, Velez CN. An epidemiological study of disorder in late child hood and adolescence: I age and gender specifie prevalence. Journal of Child Psychology and Psychiarty, 1993; 34(6): 854-867.
5. Dowall JR, Bolter CP, Flett RA, Kammann R. Psychological well-being and its relationship to fitness and activity levels. J Hum Movement Study, 1988; 1439-1445.

6. Faigenbaum AD. Strength training for children and adolescents. Clin Sports Med, 2000; 19: 593-619.

7. Gür A. Ergenlerde depresyon ve benlik saygisi arasindaki ilişki. (Published Graduate Thesis). Ankara: Hacettepe University, Social Sciences Institute, 1996.

8. İkizler HC. Spor Sağlık ve Motivasyon. 1st Edition, Istanbul: Alfa Publications, 1986.

9. Kandel DB, Davis MA. Seguale of adolescent depressive symptoms. Archives of General Psychiatry, 1986; 43: 255-262.

10. Kashani JH, Carlos GA, Bexk NC. Depression, depressive symptoms and depressed mood among a community sample of adolescents. Am J Psychiatry, 1987; 26: 541-545.

11. Koruç Z, Bayar P. Egzersizin depresyon tedavisindeki yeri ve etkileri. Journal of Sport Sciences, 2004; 15: 50-61.

12. Morgan PM, Roberts JA, Feinerman AD. Psychological effect of acute physical activity. Archives of Physical Medicine Rehabilitation. 1971; 52: 422-425.

13. Öztürk O. Ruh Sağlığı ve Hastalıkları. Nural Publications, 1988.

14. Tamer K. Beden Eğitimi ve Oyun Öğretimi. Ankara University Publications, Open Education Faculty Publications, 1988.

15. Tiryaki Ş. Sportif performans ile Edwars kişisel tercih envanteri verilerinin ilişkisi. Journal of Sport Sciences, 1991; 2(2): 32-37.

16. Van de Loo DA, Johnson MD. The young female athlete. Clin Sports Med, 1995; 14: 687-707.

17. Yavuzer H. Ana-Baba ve Çocuk. Istanbul: Remzi Publications, 1998. 